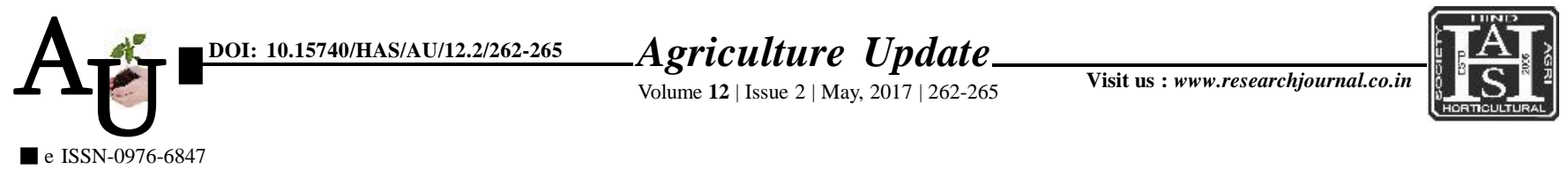

\title{
Research ARticle: Effect of internet utilization on overall performance of agricultural research scholars of agriculture science in MPUAT, Udaipur (Rajasthan)
}

\author{
口.R. CHOUDHARY AND B.S. BHIMAWAT
}

Article Chronicle : Received : 17.03.2017;

Revised : 26.03.2017; Accepted : 08.04.2017

Key Words: Internet utilization, Agricultural research scholar, Utilization pattern

Author for correspondence :

\section{L.R. CHOUDHARY}

Department of Extension Education Rajasthan College of Agricultural, UDAIPUR (RAJASTHAN) INDIA

See end of the article for authors' affiliations

SUMMARY : Internet has become a way of life for majority of higher education students all around the world. For most universities and college students, the internet is a functional tool, one that has greatly changed the way they interact with each other and with information as they go about their studies. Considering the importance of the internet utilization the present investigation "attitude and utilization pattern of internet among the research scholars of agriculture science in MPUAT, Udaipur (Rajasthan).

How to cite this article : Choudhary, L.R. and Bhimawat, B.S. (2017). Effect of internet utilization on overall performance of agricultural research scholars of agriculture science in MPUAT, Udaipur (Rajasthan). Agric. Update, 12(2): 262-265; DOI : 10.15740/HAS/AU/12.2/262-265.

\section{BACKGROUND AND OBJECTIVES}

The internet has reshaped the way we communicate, work, play and how we understand the world around us. With the rise of the internet as a digital highway for messages and images, people now have a fast, convenient and reliable means to transmit and receive information. Internet use is spreading rapidly into daily life and has an impact in many areas including the higher education system. Internet heralded the development and implementation of new and innovative teaching strategies in higher education institutions. Educators who advocate technology integration in learning process believe that it will improve learning and prepare students to effectively participate in the $21^{\text {st }}$ century workplace. It is now widely used as a research tool for news, education, entertainment and informal web-based education.

Encyclopedia Britannica defines communication as "the exchange of meanings between individuals through a common system of symbols". The word communication has been originated from the Latin word "Communis" which means common, sharing of ideas, information and feelings between individuals, so that a common understanding is established between the person sending the information and the person receiving the same. Therefore, a conscious attempt to establish commonality is communication. Communication is essential to all human associations. All type of developments is the 